\title{
Chapter 13 \\ Branding Higher Education Institutions: What It Takes to be Branded
}

\author{
Ismail Hussein Amzat
}

\begin{abstract}
Over a long period of time, the word 'brand' has been used in business, marketing and advertising to distinguish the product of one unique seller from another. Today, we are living in a world of 'customerisation' in which customers opt for a product based on their desirability and according to their favourability and loyalty to a particular product, due, perhaps, to the unrivalled quality of the brand. Given this scenario, higher institutions share similarities with business products, as the core business and product of an educational institution are teaching and learning. Hence, this chapter explains the importance of branding in higher education institutions (HEIs). It elucidates what it takes to be branded by providing some principles in creating a brand and the various steps towards branding, as well as proposes a model for the branding of higher education institutions.
\end{abstract}

Keywords Branding • Higher education institution • Marketing • Brand image • Brand identity

\subsection{Introduction}

One wonders what education has to do with branding, inasmuch as, hitherto, the term has been exclusively applied to the business sector and commercial products. Branding is an old common practice in the business world and considered to be a new concept in the educational setting. Branding in the business world today is a tool to meet the demands and satisfaction of buyers. It is a mechanism to sustain the image of a product and encourage customers to stick with the product. In a nutshell, when individuals are asked about a brand, they will not think twice before answering that a brand is a quality or famous product that companies use to attract their customers. This concept has now been borrowed by higher institutions after

\footnotetext{
I. Hussein Amzat $(\bowtie)$

Department of Educational Studies,

University of Utara Malaysia, Sintok, Kedah, Malaysia

e-mail: ihussein@uum.edu.my
} 
realising the value and importance of branding in education. This realisation is usually ignited when other players and competitors come into the picture and provide a similar service, making the marketplace more competitive.

Looking at the world today, particularly with respect to higher education institutions and their functionality, there is not much difference between education and the business sector. The higher education institutions are service providers that provide education and maintain their image and quality in teaching and learning across the lifespan, as well as gain from the intake of students and other revenue. In addition, they compete in the market with other educational institutions and create better revenue through their reputation (Black 2008). Further, the branding of educational institutions becomes important as they are considered to be great assets for the nation. In addition, with the global challenges and technology infusion, branding universities is deemed to be a solution to remain highly competitive in the marketplace and provide the ability to face those challenges (Harsha and Shah 2011). At this juncture, this chapter shares with the global audience what is at stake when higher education institutions are not saleable and marketable. It puts forward some arguments and claims by the authors concerning the importance of branding in higher education institutions (HEIs) and factors to be considered when it comes to brand development and the branding process.

\subsection{What Is Branding?}

As every organisation strives to obtain an edge in the marketplace, branding tends to be used as the key to attract customers and for product or service differentiation. Basically, to understand branding, it is necessary to understand what constitutes the brand itself. Therefore, brand and branding have been described using different adjectives and are understood from different perspectives. The brand is considered to be an integration of the brand name, goodwill and reputation (Copping 2013). While some authors believed that, it is 'a perception in the mind of target audiences (Mersino 2013, p1), people's feelings about an organization, institution, person or product which in return shapes peoples' experiences with that particular organization' (Gibby 2013). Hence, it is 'a mental expression or sign or quality (Harsha and Shah 2011, p. 2), the overall impression created in the minds of the public about an organization' (Nha and LeBlanc 2001; Teh and Salleh 2011, p. 3). According to some authors, brand is seen as 'a lifetime's uniqueness experience' (Juhdni and Salleh 2009; Teh and Salleh 2011, p. 1); it is an experience and relationship that form a connection between the organisation and stakeholders (Sharma et al. 2013). Some viewed brand as an attitude and what attitude has gotten used to, which is difficult to change, while others believed that it is about positioning. It is the 'total of all associations that are made by an organization or product' (Scarborough 2007, p. 1). However, with the different types of view and understanding, brand can simply be regarded as a name, reputation, perception, experience, positioning and association. 
According to these brand definitions, branding is the process of creating a unique name, distinctive image, everlasting reputation and experience for customers to remember, as well as a way to differentiate and distinguish top organisations or institutions from one another. In addition, branding can be considered to be an arranged plan to attract those people associated with that particular brand, which, eventually, will make the brand a desired brand (Scarborough 2007). In fact, branding is not about deceiving audiences or making something glamorous to be more saleable or attractive to target audiences. This goes against people's understanding and belief of branding. In an educational setting, despite the different studies conducted on branding in higher education institutions, there is no specific definition of a brand, what it should be and its components in the context of higher education (Bosch et al. 2006; Nha and LeBlanc 2001; Palacio et al. 2002 cited by Teh and Salleh 2011). However, the branding of an educational institution is believed to make the programmes offered by the school, college or university unique and appealing (Mersino 2013).

\subsection{The Need for Branding in Higher Education Institutions}

Do not be surprised about branding in education; it has been argued that HEIs serve a similar purpose as the private sector. As there is 'nothing new under the sun', the business sector builds long-lasting relationships with their target customers; similarly, colleges and universities do this with their graduates and alumni. On the issue of branding in higher education, we can say that only a few articles have been written concerning the importance of branding in education, although all those articles strongly agreed that the branding of HEIs should be seriously considered for obtaining more revenue and to distinguish themselves to secure customer loyalty.

The articles of Arenson (2004), Chapleo (2006), Holmes (2003), Gifford (2004) and Reader (2003) supported the idea that branding is crucial in education as it helps universities to differentiate themselves, especially in creating a brand through the strong relationship between their educational product and the students (Heaney et al. 2010). It is an effective way to gauge how a university is perceived, thought of or felt about by stakeholders (Chapleo 2013) and an asset or possible way of contributing to the financial system of the university through the attraction of associates and constituencies (Copping 2013).

Additionally, branding HEIs cannot be complacent or have second thoughts as they depend on the revenue raised from students' tuition fees. With this dependency, the dynamism of the global economy and rapid changes in the students' demographic or population have forced universities and colleges to identify their uniqueness and the benefits that the students will receive after their enrolment and graduation. At this juncture and in the pursuit of achieving a better rate in student registration, research is needed to identify and understand what the customers want and need. This will help with market strategy and in the process of branding. However, 
although the brand should remain, it is important to be aware of unexpected changes in the marketplace, as it can change according to the needs of the time. When a university is branded, it is very crucial for it to maintain its brand, and it is advised that the brand strategy used in the process should be consistent over a long period (Scarborough 2007).

Considering all the above essentials and constant changes, for HEIs to stay competitive, it is critical for universities around the world to create effective brands that will be irresistible to consumers. In the process, there might be some challenges that require universities or colleges to persevere with one brand and survey the market concerning whether the brand is relevant and in demand.

\subsection{The Importance of Brand Image and Identity}

Having a brand image or identity for a product or service is what is required in today's business and educational industries. The creation of a successful or effective brand image or identity might take every bit of an organisation's effort, and, sometimes, it can be a daunting task. For this reason, it is a prerequisite to have total comprehension of what image or identity is all about. In explaining this, brand is an association of identity, as it differentiates one from the other through its mark, symbol, slogan, tagline, specific design, colourful pattern or the combination thereof (Schiffman et al. 2005; Abbas 2014). According to Aaker (1996), brand identity is how people perceive the brand, while brand image is actually how the brand is perceived by the customers (Abbas 2014). In addition, brand image is considered to be a promise to customers, while brand identity is the output experiences of the customers in the form of trust enhancement (Ghodeswar 2008; Abbas 2014).

Nevertheless, in respect of educational institutions, their previous record and reputation play a big role in the persistence of customers with a brand. For example, an educational institution that provides low-quality education or one that has had a poor image in the past may face difficulties or challenges in transforming its image in the future, even if it has started providing quality education. Despite the institution changing its old image, students and others might find it hard to trust or believe that it has started offering quality services (Aaker 1996; Abbas 2014). Through the passage of time, the brand image or identity of an institution should be secured and protected. In doing so, it is suggested that four areas be considered: awareness, brand familiarity, image and strength of preference (loyalty). For awareness, the perceptions of the constituents or students towards their alma mater are discussed. The area of familiarity is about the connection and promotion that the university has made through word of mouth or knowledge. Image deals with the university representing what it is supposed to represent or in meeting the expectations of the people that attended. Strength of preference explains to what extent the prospective students, current students and alumni are loyal to their institutions (Gibby 2013). 


\subsection{Branding Principles}

Understanding the branding principals is an initial step in creating a successful brand. It is the means for adhering to the rules of marketing and supply according to the customers' demands. These principles should be used as a guide during the planning process, which, eventually, is supposed to help in creating effective strategies to attract clients and penetrate the market. These principles might, in some way, reduce the chances of failure or setbacks in the process of branding.

In general, according to Scarborough (2007), there are two solid and unavoidable key principles of branding in higher education institutions - differentiation and integration. Differentiation indicates that the sustainability of an organisation in the market depends on its ability to produce a product that is uniquely different and better than its competitors. However, those differentiations or separators must be developed gradually based on the association of the existing brand and should be genuinely imbued in the educational experiences (Scarborough 2007).

For integration, it involves the connection of the market with the differentiators. Hence, it is about what is communicated in the marketing that corresponds with the uniqueness of the organisation. Thus, it is about the implementation of marketing activities without exception across all university units. However, when an institution is branded, this brand is expected to drive and lead the institutional strategies. In addition, the institution itself must know how to manage the brand. As a repercussion, a brand that deviates from what the organisation is doing or market strategy will not survive for very long (Scarborough 2007). Therefore, since branding seems to be the only choice for universities and colleges to be one of the key players, four alternative or comprehensive effective principles are proposed for marketers by Barbara Apple Sullivan (2012), a founder of the Sullivan brand engagement firm, New York:

1. People's views and opinions about your college or university.

Be a good listener to know what people are saying about your institution and where you stand. This is the first principle as you need to know what the media and other communication networks say about you. Conduct a survey with students and outsiders to know what they think about your institution.

2. It goes beyond ranking.

Know your rival in the market and other institutions that compete with you with the same brand, value and services. Hence, if there are missing points or leakages in your strategy, be vigilant to know what is missing and what makes you less competitive with the others. Approach students to explore what makes them choose that particular institution. For your information, those colleges or universities that dominated the market might sometimes not be as highly world ranked or reputed as yours, but, perhaps, they knew what it takes to attract students. Therefore, this is where to use a comparison or benchmarking as an evaluation to identify your strengths and weaknesses, which, ultimately, will lead to the main differentiation between you and the institutions that are competing with you. Sometimes, an institution's brand could be its academic programmes or the 
duration of the programmes. For example, a short duration of the study or fast programme completion could be the main differentiation, as, nowadays, students love to see themselves graduating quickly and getting employed. Some universities or colleges offer a 3-year bachelor programme instead of 4 years and master's programme of 1 or 9 months instead of one and a half years or two years. In such a case, students might enrol into those institutions. In addition, traditional or face-to-face learning could be tedious or hard for some working students or for students who live far from the campus. Preferably, they may choose an institution that provides distance learning or online courses. A perfect example is the emergence of MOOCs, which has recently penetrated the market and is paving the way for global learning accessibility, flexibility, opportunity and innovation and is being used by top universities in the world, such as Harvard, Massachusetts Institute of Technology (MIT) and Stanford (Chen et al. 2013).

3. Value proposition above all.

Display what you stand for and how you want to be, and determine what constitutes your brand uniqueness, both tangibly and intangibly. Nowadays and particularly during the time when students are visiting their future institutions, the internal and external appearance of the university or college is important in swaying the students decision to choose that institution.

4. Brand honesty.

Try to admit who you are and make sure that all the points in your brand are truly delivered. Be aware that the brand is not about the beauty or how colourful your logo is and that the brand is not just for your marketing materials or your well-technologised websites, but, rather, it is the joint effort, honour and credibility in the university community as a whole.

Adherence to these basic principles before embarking on a branding mission in higher education institution is advised. Although the principles are not expected to answer all your questions or solve all your problems, it will at least provide general and basic principles that the majority of the authors agree upon and which other authors might build upon and extend.

\subsection{Steps Towards Branding}

Since branding is seen as an important tool worldwide in any kind of organisation to improve its product or service and mainly to entice customers, it is absolutely crucial, especially in the educational setting, to know the steps and techniques before creating a brand. In addition, it is also necessary to be aware that whatever brand tactics or plans you have, it should relate to the mission and value of the institution. Harsha and Shah (2011) identified five universal plans or what can be considered as tactics: 
1. Understand what people want.

In the case of HEIs, there should be empirical studies to determine the tastes of the constituents and identify what they want from the institution.

2. Identify market segments or, as I prefer to term it, 'market weaknesses exploration' that an institution should exploit.

This calls for defining the features of each segment by exploring the motivation factors and challenges that might stand in the way of the institution achieving its objectives.

3. Determine brand attributes that are lesson barriers.

Doing this helps to penetrate the market to determine what students want or what type of institution the prospective students are looking for. This is where an institution's reputation, experience, programmes and tuition are crucial.

4. Utilise brand attributes for positioning.

This is where an institution has to differentiate itself from its competitors by exploring its strengths to exploit the weaknesses of its competitors in the marketplace. In addition, it is about utilising the niche area and seizing the opportunity with a strong defence against any competitors in the market.

5. Differentiate your institution with unique campaigns, promotions and communication. This leads to the corporate branding message for the purposes of marketing in that all communications and voices should be united in conveying one message and value to distinguish your institution from the others.

To some extent, the branding of higher education institutions might go beyond marketing and advertising as the understanding of branding in universities has to be attained by the staff across all the units and should be generally welcomed and receive positive acceptance.

\subsection{The Role of Marketing}

The universities and colleges of today and tomorrow are advised to take a stance by creating their brands and market differentiation. When these brands are created, it should be tightly integrated with the business strategies of the university or college, as it will help in establishing an operational model (Dwyer 2014).

As the battle and competition between organisations intensify in enticing customers, marketing becomes a platform to communicate brand uniqueness and differentiation. In addition, marketing could be used as a tool to display or explain what you have in stock for your clients, where you can promote your brand and how you can convince your customers concerning the factors that make your brand better than those of your competitors. Without doubt, marketing helps to explain what the organisation is offering to meet the market needs and demands using communication and distribution to attract customers (Beneke 2011).

As is well known, especially in the context of education, the main purpose and function of marketing in higher education is to help promote the institution's brand 
(Beneke 2011). Marketing in higher education refers to the analysis, planning, implementation and control of programmes for the sake of the market target exchange to achieve the institutional objectives (Kotler and Fox 1995; Beneke 2011). In keeping with the market demands or segment, students are considered to be the main consumers (Kantanen 2007; Abbas 2014), which adds to the struggle of universities and colleges to compete for students, faculty research funds and donors using strong marketing strategies.

According to the Michigan State University brand standard (2013), great or consistent brands create strong relationships with their audience or customers. Notwithstanding, these brands are always recognised by their customers who know what they represent the moment they are displayed in the market. An effective brand communicates the same value despite it communicating with different types of audience on different occasions. In addition, since marketing is perceived to be the way to reach customers and meeting their needs and demands, the same marketing has often been used worldwide by some top universities, such as Northwestern University and the University of Cambridge, as promotional tools to market themselves using advertisements as a promotional tactic (Schwartz 1993; Rogers 1998; Beneke 2011). Furthermore, the role of marketing in education not only connects the brand with the customers, it also paves the way for higher education to be marketed and provides the means for exchange as well as accessibility. In addition, it provides revenue and funds to facilitate teaching, learning and research (Bhayan 2010; Heaney et al. 2010).

\subsection{The Benefit of Brand and Branding}

Building a brand might not be an easy task; in addition, branding an organisation may require a long process and strategic planning. However, in return, it pays well as there are numerous opportunities and benefits. When the quality of a brand, image and identity are consistent and sustainable, it gives credibility and provides benefits to the organisation as well as consumers, especially in the educational arena. As when a university or college is unable to maintain its teaching quality, research, service and ability to stay on top in the world university ranking, it not only benefits the institution but also the staff, students, stakeholders, society and nation. According to Keller (2008), brand benefits customers in different ways, such as:

(a) Customers benefit as brand determines the source of the product.

(b) Brand benefits, as a brand reduces risk and assists in reducing cost.

(c) Brand benefits, as a brand is the promise made by the maker to keep their promise in the product and a sign of quality.

(d) Brand benefits, as producers or manufacturers take the responsibility for the brand. It benefits the producers and manufacturers as a brand protects and legalises the unique features of the brand. 
(e) In addition, it benefits these two parts as brand infuses quality to satisfy customers' tastes, endows products with unique association, provides competitive advantage and could be used as a source of income and return (Beneke 2011).

Furthermore, brand goes beyond the logo and it is the customers that define the brand not an organisation. Thus, it is the students' experiences that give the brand its reputation (Gibby 2013). Consequently, the university will start gaining and benefiting from the brand once students start sharing their brand experiences in public and the media. This makes the brand a powerful marketing strategy and helps the university penetrate the market to find their audience and niche market, especially during the recruitment and admission period (Gibby 2013).

\subsection{Challenges in Branding Higher Education}

In an era of competition and comparison, higher education institutions or universities are compelled to distinguish themselves from other universities by creating brands and identities. However, the question to ask is, to what extent is this brand suited to the customers' tastes and able to compete with the existing brands in the market (Higher Education Network 2012)? It was made clear in the European CASE conference on the distinctiveness of higher education that universities are in a tight situation and that they have to distinguish themselves in the marketplace and 'stand out' among the institutions that provide the same services.

Moreover, universities have to pursue excellence that can be used to persuade or influence students during their intakes to make the right choice through comparison. As branding is about distinctiveness, a research of two years by Oxford Brookes University, funded by the Higher Education Funding (HEFCE), defined distinction as 'the vehicle which enables an organization to achieve many of its strategic goals through being memorable, authentic, and clearly articulating what it has to offer to the people that are important to it' (p. 1). However, moving towards distinction helps internally to increase the sense of belongingness and loyalty among the students and staff (Higher Education Network 2012, p. 1). Below are some of the challenges that are being faced or lie ahead for higher education institutions across the globe:

\subsubsection{Privatisation, Decentralisation and Internationalisation}

The issues of privatisation, decentralisation and internationalisation have come into the picture and added to the challenges of HEIs. These issues have gained momentum and popularity and led to the establishment of private universities around the world. Since the concept of branding has been applied in HEIs, it has impacted on people's choices, especially for students to vigilantly select their universities or 
colleges by looking at the courses offered by these institutions before enrolment (Harsha and Shah 2011). This has led to the universities and colleges vying and competing with each other to promote their brand and monopolise the market in terms of student enrolment.

\subsubsection{Challenge Within}

External associates can pose a serious challenge for the universities, such as major donors and sponsors becoming too demanding or tending to misuse the brand or the name of the brand. In addition, within the universities themselves, it could be difficult to have one unified brand management, especially with faculties, centres or departments that are decentralised or autonomous inasmuch as they tend to have their own separate brand identity. Therefore, when a university practises good management, its brand can be protected as an asset and promotional tool for sustainability (Copping 2013).

\subsubsection{Competition Between Sectors}

Although business and educational services seem to be similar, their challenges might vary, as educational institutions are non-commercial providers that might need to be smarter and more observant in terms of marketing and branding. Again, the challenges for educational institutions may take a different form as educational brands rely on long-term consumption compared with noneducational organisations (Vijander 2007; Abbas 2014).

\subsubsection{Supply and Demand}

The supply and demand between students and HEIs have moved to a higher level as the current trend is for universities and colleges around the world to apply marketing theories and principles to attract their customers and gain competitive advantage (Hemsley-Brown and Oplatka 2007; Abbas 2014). These theories and principles were further applied due to the demand from populous continents, such as Asia and Africa. Furthermore, these demands have gained momentum in that the USA and other Western countries, as suppliers, have to find leverage to accommodate these demands (Abbas 2014).

In addition, these theories and principles are applied as countries around the world are competing to reduce the rate of illiteracy, and students who have newly completed their college or secondary school education are moving to the cities and 
capitals to enrol in their desired or dream universities. As a result of these changes, universities are endeavouring to create a winning or super-brand to woo students to choose their universities with the help of their strong marketing strategies and brand management (Abbas 2014).

\subsubsection{Modernisation}

The backlash against tuition fees, the war against traditional learning posed by online or distance learning and the increment in student mobility are some of the reasons why universities and colleges need to be branded to differentiate and communicate with prospective students. In addition, branding not only helps in terms of students' fees and differentiation but also in terms of universities achieving their vision through their mission statement (McKee and O'Malley 2008).

\subsubsection{Coping with Students' Choices}

Nowadays, students from top universities and modern schools value branding to some extent. Hence, Abbas (2014) found that students want their universities to be branded and to see their university's management using various sources to promote their universities. Yet again, students believe in marketing principles and strategies as they want the name of their universities to be heard in the social media.

Furthermore, the history, establishment and reputation of a university are factors that have a major influence on the choices of the students. It is very likely that prior to enrolling, students will check the profile of the university and the students who have graduated from that university. Sometimes, even the physical aspects of the university are taken into consideration as students these days give great value to the location, environment and spaciousness of the institution, as well as the beautiful architectural designs of the buildings, well-kept gardens and modern facilities (Heaney et al. 2010).

\subsubsection{Sustainability}

In an era of dramatic changes, the biggest problem or challenge facing colleges and universities is the maintenance of their brand or position among constituencies (Herr 1996). Conversely, branding should stay intact with stakeholders in terms of the sense of protecting the core value and mission of an organisation as well as maintaining this value through visual identity that will withstand all types of modern changes and circumstances throughout the lifetime (Rosen 2012). 


\subsection{Branding Model}

Figure 13.1 presents a model of branding higher education institutions. The model was created based on the collective suggestions of the authors and ideas from the literature. The model takes into consideration that for an educational institution to be branded, three steps need to be followed - brand principles, image and identity and branding of the institution. This model suggests that knowing the brand principles is the first step to building a brand and helps in determining the 'do's and don'ts' in the process of creating a brand. The second step is about creating a brand image and identity as brand identity comes from the institution about the meaning of the brand and how the institution wants the brand to be identified. Brand image pertains to how the brand is perceived by the people (students, stakeholders, consumers and society). Therefore, it is essential to create a brand image and identity for these purposes. The third step is the process of branding the institution to make it a global trademark. This part provides some steps and emphasises the importance of having a unique marketing strategy as marketing plays a big role in executing the plan. In addition, it stresses considering the challenges during the branding process.

\subsection{Conclusion}

This chapter attempted to shed light on the new trends in fast-forwarding higher education institutions through branding. It discussed the new paradigm shift in education in that the reputation of the university or college stands as a brand in

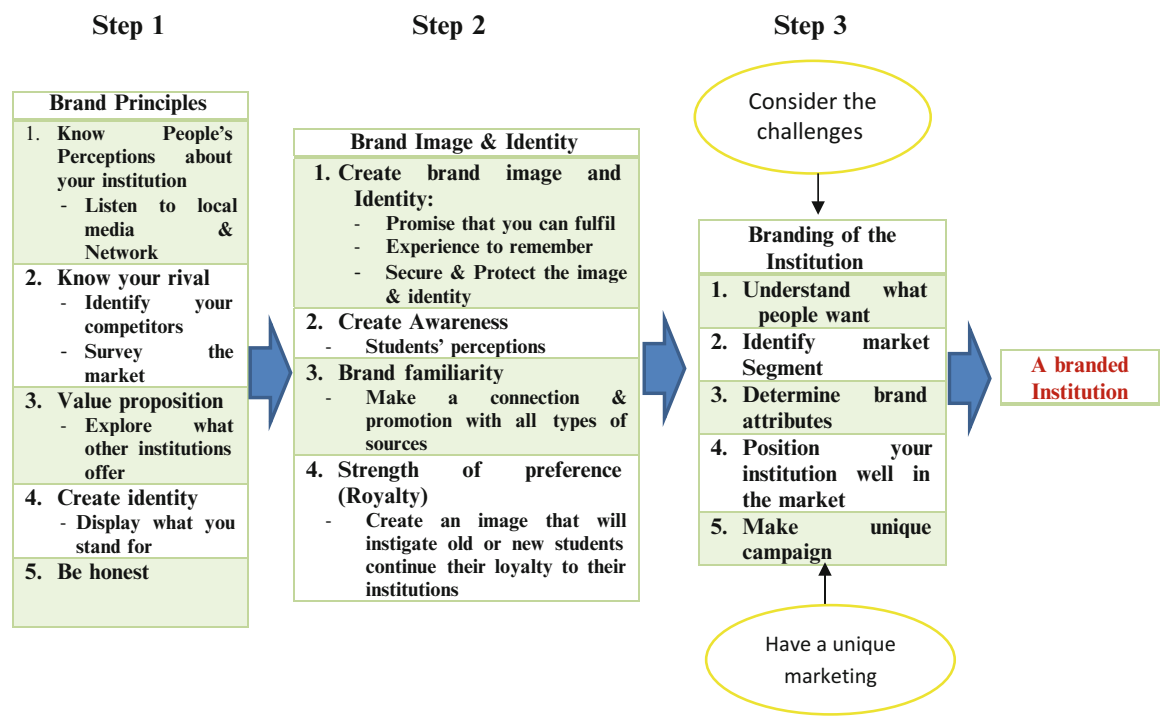

Fig. 13.1 Model for branding higher education institution 
promoting the institution and attracting customers. It shared the concept of branding in the industrial sector and its application in education. It discussed the ideas of the experts and scholars concerning why branding in education is needed. The chapter provided some brand principles and discussed the importance of creating a brand image and identity as well as some steps in branding. In addition, it highlighted some benefits of branding HEIs and argued the role of marketing and the challenges ahead. Last, but not least, this chapter summed up what has been stated and argued in the literature by creating a model for HEIs to follow in designing a brand and branding an institution.

Furthermore, this chapter argued that as far as quality education, reputation and experience are concerned, branding of higher institutions is inevitable. Indeed, students today live sophisticated lifestyles, with expensive tastes, uniqueness and choosiness, have high expectations and are technology savvy. They are sensible in making the right choices, together with their parents in choosing a brand university or college. In addition, they are able to research the educational markets and are well informed concerning leading institutions around the world. These days, branding higher education is not simply about supplying quality education, it is also about the institution's reputation in the global marketplace and its achievements in terms of the employability of its alumni, the productivity of the alumni in the workplace, the irrefutable standing that the institution has among its customers, its experience and enduring global image. Therefore, to compete globally and sustain internationally, universities or colleges should strive to create an identity through branding that is distinct and that will distinguish them from the other brands in the marketplace.

The important role that marketing plays in branding higher education institutions is undeniable, especially in identifying students' needs, positioning and promotion. Marketing can also be used as a mechanism to explore what the market is demanding, such as knowing the competitors and the kinds of service or educational programme they are offering and providing and examining what attracts students to a particular university or college, and what makes their logo captivating and their brand identity irresistible. This journey of exploration will help the institutions identify their strengths and weaknesses and then capitalise on the strengths and improve on the weaknesses.

Since educational institutions depend heavily on students' fees as their primary revenue with support from the consumers and stakeholders as the second revenue, higher education institutions need to create a unique brand to entice their associates or clients. Although the process of becoming a brand as an educational institution might take a while compared to a business setting, however, with the help of consistency in and continuity of excellent performance, sooner or later, what you sow will be reaped, and the performance will gain recognition worldwide. Ultimately, the reaping of benefits not only belongs to the institution but also to the students, employers, parents, government and society.

In summation, as long as universities and colleges depend on students' tuition and registration for their revenue, as long as the customers (students and parents) have choices and there are a variety of products or brands on the market and all the time as long as university ranking is used to benchmark the research results of a 
university and its productivity, universities and colleges should create brands to attract their customers to enable them to survive in the global market and outdo the competitors. Indeed, to be a branded institution, one must be able to answer the following questions:

1. What is your brand?

2. What type of brand do you want to create?

3. What is your brand identity?

4. Who are your target audiences, clients or customers?

5. What makes you different?

6. What are your marketing strategies?

7. Does your marketing strategy align with your brand identity, mission and value of your institution?

\section{References}

Aaker, A. D. (1996). Building strong brands. Chatham: Simon \&Schuster.

Abbas, S. A. (2014). Brand management of higher education institutions. International Journal of Innovative and Applied Research, 2(6), 151-172.

Arenson, K. W. (2004, November 7). Branded nation. New York Times, p. 10.

Beneke, J. H. (2011). Marketing the institution to prospective students - A review of brand (reputation) management in higher education. International Journal of Business and Management, 6(1), 16-28.

Bhayan, A. (2010, January 4). Marketisation of Higher Education in the Gulf. Khaleej Times. http://www.khaleejtimes.com/DisplayArticle.asp?xfiles=data/opinion/2010/

Black. J. (2008, January 7). The branding of higher education. SEMWorks. Retrieved from http:// www.semworks.net/papers/wp_The-Branding-of-Higher-Education.php

Bosch, J., Venter, E., Han, Y., \& Boshoff, C. (2006). The impact of brand identity on the perceived brand image of a merged higher education institution: Part one. Management Dynamics, 15(2), $10-30$.

Chapleo, C. (2006). Barriers to brand building in UK universities? International Journal of Nonprofit and Voluntary Sector Marketing, 12(1), 23-32.

Chapleo, C. (2013). Is branding maligned and misunderstood? The World Reputation Rankings. Retrieved from http://www.timeshighereducation.co.uk/world-university-rankings/2013/ reputation-ranking/analysis/chris-chapleo

Chen, X., Barnett, D. R., \& Stephens, C. (2013). Fad or future: The advantages and challenges of massive open online courses (MOOCs). Presented at the research-to practice conference in adult and higher education. St.Charles: Lindenwood University, 20-21 Sept.

Copping, D. (2013). A university's brand is of real commercial value. The World Reputation Rankings. Retrieved from http://www.timeshighereducation.co.uk/world-universityrankings/2013/reputation-ranking/analysis/a-universitys-brand

Dwyer, M. (2014, October 15). Branding tomorrow's University. Interbrand. Retrieved from http://interbrand.com/en/views/45/branding-tomorrows-university

Ghodeswar, B. M. (2008). Building brand identity in competitive markets: A conceptual model. Journal of Product and Brand Management, 17(1), 4-12.

Gibby, T. (2013). Hobsons' president says brands really do matter. The World Reputation Rankings. Retrieved from http://www.timeshighereducation.co.uk/world-university-rankings/2013/ reputation-ranking/analysis/hobsons 
Gifford, C. (2004, November). Lessons from the commercial world. Education Marketing Magazine. Iss.33. Retrieved from www.heist.co.uk/corporate_identity/05270605.cfm. Accessed 8 Sept 2005.

Harsha, P. P., \& Shah, S. (2011). Creating brand value of higher education institution. IJMT, 19, 2. Retrieved from http://ijmtpublication.com/files/IJMT_volume\%2019_2_13r.pdf.

Heaney, J.-G., Ryan, P., \& Heaney, M. F. (2010). Branding private higher education institutions in Australia to international students. Academy of World Business Marketing and Management Development Conference. Oulu, 12-15 July, viewed 26 Mar 2011. http://www.consulted.biz/ Papers.htm

Hemsley-Brown, J.V., \& Oplatka, I. (2007). Market orientation in HE institutions: Development of a pilot instrument. Paper at the Academy of marketing (SIG) Higher Education Marketing, Eötvös Loránd University in Hungary, Budapest, 4-6 Apr 2007.

Herr, P. (1996). Higher education institutional brand value in transition: Measurement and management issues. Forum Futures, 2001, 23-26. https://net.educause.edu/ir/library/pdf/ffp0104s. pdf

Higher Education Network. (2012, June 19). Branding in higher education - Just how feasible is distinctiveness? The Guardian.http://www.theguardian.com/higher-education-network/ blog/2012/jun/19/distinctiveness-in-higher-education

Holmes, S. (2003). Branding: What's it all about and how do we build it? Education Marketing Magazine, (29), July. www.heist.co.uk/corporate_identity/12150605.cfm. Accessed 8 Sept 2005.

Juhdni, N. H., \& Salleh, H. A. M. (2009). Chapter 7 - Brand awareness and brand meaning in cultivating service brand equity for Malaysian higher education. In Aliah Hanim Mohd. Salleh, Ahmad Azmi M. Ariffin, June M.L. Poon, \& Aini Aman (Eds.) Services management and marketing studies in Malaysia (pp. pp. 141-159). Bangi: UKM-Graduate School of Business, Universiti Kebangsaan Malaysia.

Kantanen, H. (2007). Do we live up to our brand propositions? Organisational identity, university image and stakeholders perspectives. In B. Stensaker \& V. D'Andrea (Eds.), Branding in higher education. Exploring an emerging phenomenon (EAIR series research, policy and practice in higher education, pp. 56-72). Amsterdam: EAIR.

Keller, K. (2008). Strategic brand management - Building, measuring and managing brand equity (3rd ed.). Upper Saddle River: Pearson Prentice Hall.

Kotler, P., \& Fox, K. (1995). Strategic marketing for educational institutions (2nd ed.). Englewood Cliffs: Prentice Hall.

McKee, S., \& O’Malley, B. (2008). 50 best branding ideas. UB University Business, Dec 2008. http://www.universitybusiness.com/article/50-best-branding-ideas

Mersino, D. (2013, September 24). Not evil: Why branding matters in education. Ingeniosus. Retrieved from http:/www.ingeniosus.net/archives/ not-evil-why-branding-matters-in-education

Michigan State University. (2013). Michigan State University: Brand Standards. (Version 5). Retrieved from http://cabs.msu.edu/documents/MSU-brand-standards-7-23-14.pdf

Nha, N., \& LeBlanc, G. (2001). Image and reputation of higher education institutions in students "retention decisions". The International Journal of Educational Management, 15(6), 303-311.

Palacio, A. B., Meneses, G. D., \& Perez, P. J. (2002). The configuration of university image and its relationship with the satisfaction of students. Journal of Educational Administration, 40(5), 486-505.

Reader, P. (2003). Towards the globalisation of the brand. Education Marketing Magazine, 28, 26-27.

Rogers, D. (1998). Cambridge goes to market. Marketing, 9, 19.

Rosen, D. (2012). Branding in higher education: What it is and why it matters. EDUNIVERSE. Retrieved from http://eduniverse.org/branding-higher-education-what-it-and-why-it-matters 
Scarborough, E. (2007). The branding of higher education: The great awakening in the hallowed halls of Academia. SIMPSONSCARBOROUGHT. Retrieved from HTTP://MAGAZINE. AUSTINCOLLEGE.EDU/FALL09/WEBXTRAS/BRANDING_HALLOWEDHALLS_ SCARBOROUGH.PDF

Schiffman, L., Bednall, D., O’Cass, A., Paladino, A., \& Kanuk, L. (2005). Consumer behavior (3rd ed.). Sydney: Pearson Education Australia.

Schwartz, J. D. (1993). The school as brand: Marketing Northwestern. Brandweek, 34(45), 28-29.

Sharma, S. A., Rao, V. R., \& Popli, S. (2013). Measuring consumer-based brand equity for Indian business schools. Journal of Marketing for Higher Education, 23(2), 175-203.

Sullivan, A. P. (2012, August). How to make a college an irresistible brand. Forbes.http://www. forbes.com/sites/forbesleadershipforum/2012/08/23/how-to-make-a-college-anirresistible-brand/

Teh, G. M., \& Mohd Salleh, A. H. (2011). Impact of brand meaning on brand equity of higher educational institutions in Malaysia. World Journal of Management, 3(2), 218-228.

Vijander, S. (2007). Indian higher education: Commodification and foreign direct investment. The Marxist, 23(2), 45-188. 